\title{
A KELET-AFRIKAI KÖZÖsSÉG TŐKEVONZÓ KÉPESSÉGE - A COVID-19 KIHÍVÁSAI
}

\author{
Investment attractiveness in the East African Community - \\ Challenges of COVID-19
}

\author{
Kis Katalin ${ }^{1} 2$
}

\begin{abstract}
Absztrakt: A Kelet-afrikai Közösség megalakítása hosszú évtizedekre nyúlik vissza, de az ezredfordulót követő újraszervezés és az integráció mélyítése járult hozzá jelentősebben kereskedelmük emelkedéséhez. Az export-orientált gazdaságpolitikák következtében az integráció tagjai egyre jelentôsebben kapcsolódtak be a világkereskedelembe és a globális termelési láncokba. Azonban a hazai tőkeellátottság hiányában a Kelet-afrikai Közösség tagjai jelentősen támaszkodnak külső forrásokra, köztük a külföldi tőkebefektetésekre (FDI). A tagországok egyre több múködőtôkét vonzanak, ami a kitermelőipar és feldolgozóipar mellett már a technológiai és telekommunikációs iparágakba is áramlik. Ezt magyarázhatja, és egyben ösztönözheti a Kelet-afrikai Közösség belső kereskedelmében a magasabb hozzáadott értékű termékek egyre nagyobb súlyát. Azonban az Afrikába irányuló befektetések alakulását nagyban befolyásolják a nemzetközi termelésben végmenő tendenciák. A COVID-19 pandémiás helyzet megjelenése a jelenlegi nemzetközi termelési rendszer megváltozásához vezet, ami alól az afrikai országok sem vonhatják ki magukat, így a Keletafrikai Közösség előtt is kihívások sora áll.
\end{abstract}

Kulcsszavak: Kelet-afrikai Közösség, FDI, kereskedelem, COVID-19

Abstract: The formation of the East African Community dates back many decades, but the reorganization and deepening of integration after the turn

\footnotetext{
${ }^{1}$ Kis Katalin, Nemzeti Közszolgálati Egyetem - Közigazgatás-tudományi Doktori Iskola, PhD-hallgató e-mail: Kis.Katalin@,hallg.uni-nke.hu

A szerző további munkásságát lásd a Magyar Tudományos Művek Tára oldalán: https: / / m2.mtmt.hu/gui2/?type $=$ authors\&mode=browse\&sel $=10045377$

2 A tanulmány Az Innovációs és Technológiai Minisztérium ÚNKP-19-3-I-NKE-3 kódszámú Új Nemzeti Kiválóság Programjának szakmai támogatásával készült.
} 
of the millennium provided more support for the increase in trade. As a result of export-oriented economic policies, members of integration have also become increasingly involved in world trade and global production chains. However, in the absence of domestic capital, members of the East African Community rely heavily on external sources, including foreign direct investment (FDI). Member States are attracting more and more capitals, which are already flowing into the technology and telecommunications industries in addition to the extractive and manufacturing industries. This may explain and encourage the growing weight of higher value-added products in intra-trade. However, investment in Africa is strongly influenced by trends in international production. The consequences of COVID-19 will change the current international production system, from which African countries will not be able to avoid, thus the East African Community will also face a number of challenges.

Keywords: East African Community, FDI, trade, COVID-19

\section{BEVEZETÉS}

A Kelet-afrikai Közösség (angol elnevezés: East Africa Community, rövidítve: EAC) 177 millió állampolgárával, 2,5 millió négyzetkilométernyi földterületen, 193 milliárd dollár összeértékű bruttó hazai termékével és egy kiemelkedő növekedési potenciállal nagy stratégiai és geopolitikai jelentőséggel bír a régióban, ami a kereskedelem ösztönzése és a befektetéseket illetően kiemelten jelentkezik. ${ }^{3}$ Azonban a koronavírus megjelenése a gazdaságokat sok szempontból negatívan érinti, köztük szerepel a külföldi tőkebefektetések drámai visszaesése is. Az előrejelzések szerint a globális tőkeáramlások 2020-ban akár 40 százalékkal is csökkenhetnek a 2019-es 1,54 milliárd dolláros szinthez képest, ami a befektetések terén 15 éves mélypontot jelent. ${ }^{4}$

Azonban a koronavírus megjelenése számos az elmúlt időszakban előtűnő megatrendet felgyorsíthat, köztük a regionalizációt is. Számos nemzetközi szervezet és fejlesztési program, köztük az ENSZ Afrikai Gazdasági Bizottsága és az Afrikai Unió Új partnerség Afrika fejlesztéséért (angol elnevezés: New Partnership for Africa's Development, rövidítve: NEPAD)

${ }^{3}$ EAC, 2020.

4 WORLD INVESTMENT REPORT, 2020. 10. o. 
programja hangsúlyozza, hogy az afrikai régió fejlesztésében nagy szerepe lehet az országok közötti kereskedelmi megállapodások megkötésének, mi több, regionális integrációk kialakításának. ${ }^{5} \mathrm{Az}$ integrációhoz való tartozás javíthatja az alkupozíciókat a külső szereplőkkel szemben, továbbá a belső vámok és kereskedelmi korlátozások lebontása ösztönözheti a belső kereskedelmet, ami az országok külső függését csökkentheti. ${ }^{6}$ Afrikában számos regionális integráció múködik, melyek működése már hosszú évtizedekre visszanyúlik és az integrációk céljai között mindig prioritásként kezelik a kereskedelem növelését, így fontos vizsgálni, hogy mely tényezők befolyásolják a tagországok kereskedelmét.

A tanulmány célja, hogy bemutassa a Kelet-afrikai Közösség kereskedelmének szerkezetét és a régióba áramló külföldi tőkebefektetések alakulását. Ehhez a tanulmány első részében az irodalmi áttekintés során feltárom azokat a tényezőket, amelyek hatással lehetnek a regionális integrációk kereskedelmének alakulására, kiemelt figyelmet szentelve a szubszaharai régióba áramló külföldi tőkebefektetéseknek, annak sajátosságai miatt. Ezt követően a Kelet-afrikai Közösség kereskedelmi és befektetési sajátosságai következnek. A tanulmány végén pedig kitérek a koronavírus megjelenését követő kihívásokra, veszélyekre és lehetséges hatásokra.

\section{A KÜLFÖLDI TŐKEBEFEKTETÉSEK KERESKEDELEM-ÖSZTÖNZŐ SZEREPE - AFRIKAI PERSPEKTÍVÁK}

Afrikában a hatékony kereskedelem előtt még ma is számos akadály áll, így a szubszaharai régió számos területen fejlesztésre szorul. A megfelelő közút- vagy vasúthálózat nélkül külkereskedelmük ösztönzése nehézkes. A kereskedelem alapvető tényezője a megfelelő infrastruktúra megléte, amely támogatja az áruk akadálymentes áramlását. ${ }^{7}$ Az úthálózati hiányosságok kiszámíthatatlan késések - a gazdasági ágazatokat eltérő mértékben érintik. A romlandó, feldolgozatlan mezőgazdasági termékek szállításakor a kár hatványozottan jelentkezik, holott ma még számos afrikai ország e termékek exportjára építi gazdaságát. ${ }^{8} \mathrm{Az}$ intézményi hiányosságok - a magas kereskedelmi költségeken keresztül - az importot és az exportot is hátrál-

\footnotetext{
5 TARrósy, 2013. 275-298. o.

${ }^{6}$ UNCTAD, 2009.

${ }^{7}$ FRANCOIS-MANCHIN, 2013. 165-175. o.

${ }^{8}$ CHRIST-FERrANTINO, 2011. 1749-1759. o.
} 
tatják. Az afrikai országok gazdaságában számos lehetőség rejlik, de a kiaknázásukhoz szükséges az infrastruktúra hiányosságainak kezelése, amely a strukturális transzformációt és a piaci integrációjukat is segíti. ${ }^{9} \mathrm{Az}$ infrastruktúra-fejlesztések és a gazdasági növekedés közötti pozitív kapcsolatot már afrikai viszonylatban is igazolták. A jóléti hatások - az alacsony ellátottsági szintből fakadóan - a kevésbé fejlett régiókban élénkebben jelentkeztek. ${ }^{10}$ A fejlesztések a külkereskesedelem versenyképességének növelésén keresztül ösztönzik a gazdasági növekedést, hiszen a javuló infrastrukturális-ellátottság kedvezőbb üzleti környezetet jelent, ezzel a külföldi működőtőke előtt is megnyitva a kapukat.

Az 1990-es évektől gyorsuló gazdasági növekedés a szubszaharai régióban a pénzügyi szolgáltatások és a kereskedelmi bankrendszer fejlődésével is társult. A pénzügyi liberalizáció, a kapcsolódó reformok, az intézményi és szabályozói fejlesztések, ahogy a napjainkban terjedô határon átnyúló, pánafrikai bankközi együttmúködések is javították az afrikai bankszektor hatékonyságát. Azonban az afrikai kontinens számára szükséges fejlesztések saját tőkéből való finanszírozása a hazai és regionális bankrendszer alacsony tőkekoncentrációja miatt jelenleg még mindig nem megoldható. ${ }^{11}$

Az elegendő hazai tőke hiányában pedig, a külső források kiemelt szerepet töltenek be az afrikai országok gazdaságában. ${ }^{12}$ Ezt alátámasztja az is, hogy már számos elemzés született a külső források kereskedelemre gyakorolt hatásáról. A szakirodalomban a külső források között kiemelt figyelmet fordítanak a közvetlen mûködőtőke-befektetésekre, és a kereskedelem-ösztönző szerepüket is hangsúlyozzák, így a tanulmányban is e mentén tekintem át a kereskedelemre gyakorolt hatásokat. ${ }^{13}$

Az afrikai országok számára a leghatékonyabb forrás a közvetlen működőtőke-befektetések (angol elnevezés: Foreign Direct Investment, rövidítve: FDI) lehetnek. A beáramló technológiai transzfer hozzájárulhat a termelékenység javulásához, a külföldi vállalatok jelenléte pedig növeli a versenyt, ami a hazai vállalatokat hatékonyságuk javítására ösztönözheti. ${ }^{14} \mathrm{~A}$ nagy helyi piacok, az erőforrással való ellátottság, a jó infrastruktúra, az

\footnotetext{
9 AREZKI-SY, 2016. 22. o.

${ }^{10}$ KodongO-OJAH, 2016. 105-125. o.

${ }^{11}$ EIB, 2015. 9-39- o.

12 Amighini-SANFilippo, 2014. 1-17. o.

${ }^{13}$ FUCHS ET AL., 2014. 172-199. o.

14 AMighini-SANFILIPPO, 2014. 1-17. o. és SZENT-IVÁNYI-VIGVÁRI, 2012. 51-72. o.
} 
alacsony infláció és a kiszámítható jogi és befektetői környezet pozitív hatással van az FDI beáramlására, míg a korrupció és a politikai instabilitás ellentétes hatást vált ki, ezáltal az exportot is negatívan érintve. ${ }^{15}$ Ezt támasztja alá, hogy az afrikai országokba áramló FDI eloszlása sem egyenletes, hiszen például az ázsiai tőkebefektetések főként az ásványi nyersanyagban gazdag országokba áramlanak. A jól múködő helyi pénzpiacok is fontosak, hiszen az afrikai országokba áramló FDI kapcsolatot mutat a magánszektor hitelfelvételeivel és megtakarításaival, ami csak a funkcióit megfelelően ellátó pénzügyi rendszer keretein belül lehetséges. ${ }^{16}$

A regionális integrációk léte pozitív hatással lehet az FDI beáramlására. A közös szabályok erősíthetik a politikai stabilitást, ösztönözve a tagokat a demokratikus választások lefolytatására. ${ }^{17}$ A regionális integrációk potenciálisan nagyobb piacot jelentenek és a beáramló FDI a technológia fejlesztésen keresztül, főként az alacsony technológiát igénylő iparágakban, mint a mezőgazdasági termékek feldolgozása és a textilipar, bővítheti az exporttermékek körét, ami a belső kereskedelem növekedéséhez is hozzájárulhat. ${ }^{18} \mathrm{~A}$ nagyobb kereskedelmi nyitottság és a beáramló tôke a gazdasági növekedést is ösztönözheti. ${ }^{19}$ Másfelől az eltérô fejlettségi szintből következően egyes tagországokban nagyobb lehet a hatás, mivel a kvalifikáltabb munkaerô és a stabilabb pénzügyi környezet több múködőtôkét vonzhat, a többi tagország kárára. ${ }^{20}$

A szakirodalmi áttekintés alapján a közvetlen tőkebefektetések hatékony forrást jelenthetnek a kereskedelem ösztönzése terén. Ebből kifolyólag érdemes vizsgálni a Kelet-afrikai Közösségbe áramló külső források alakulását és belső kereskedelemre gyakorolt hatását. Persze ahhoz, hogy reális esély mutatkozzon az integrációk belső kereskedelmének növelésére, a megfelelő exportstruktúra is szükséges, így elengedhetetlen elemezni a kereskedelem összetételét is. ${ }^{21}$

\footnotetext{
15 ASIEDU, 2006. 63-77. o. és MOUSSA ET AL., 2016. 163-173. o.

16 ADJASI ET AL., 2012. 429-439. o.

17 AsIEDU, 2006. 63-77. O

18 Amighini-SANFILIPPO, 2014. 1-17. o. és MOUSSA ET AL., 2016. 163-173. o.

19 AdAMS - Evans Osei OPOKU, 2015. 48-56. o. és TAHIR ET AL. 2015. 82-89. o.

${ }^{20}$ JAUMOTTE, 2006. 32. o.

${ }^{21} \mathrm{IMF}, 2017$.
} 


\section{KERESKEDELEM ÉS KÜLFÖLDI TŐKEBEFEKTETÉSEK A KELET- AFRIKAI KÖZÖSSÉGBEN}

A kereskedelmi megállapodások megkötésének számos motivációját sorolja fel a szakirodalom. Az egyik legalapvetőbb feltételezés, hogy az egyik ország tevékenysége hat a szomszédos országra is, ezt nevezzük határonátnyúló hatásnak. Minden ország arra törekszik, hogy a saját termelési tényezőit a leghatékonyabban használja ki (relatív olcsóbb import az exporthoz képest) és növelje a nemzeti jövedelmét. ${ }^{22} \mathrm{~A}$ megállapodásokat lehet regionális és multilaterális szinten is értelmezni. A multilaterális egyezmények egyszerűbb szabályokon alapulnak, amelyek nagyobb teret engednek a résztvevő országoknak, hogy koordinálják a vámszinteket és viszonozzák a piachoz való hozzáférését. ${ }^{23} \mathrm{E}$ mellett számos egyéb gazdasági tényezôt lehet felsorolni, amelyek ösztönzik a regionális integrációk megalakítását:

- növekvő felvevőpiac: a nagyobb piac méretgazdaságossági szempontokból kedvezőbb, továbbá növelheti a külföldi működőtőke befektetések nagyságát;

- csökkentheti a jövőbeli kereskedelem bizonytalanságát: ha aláírtak egy megállapodást, akkor az abban foglaltak betartására kötelezik magukat;

- kereskedelem politikai változtatásokat jelezhet előre: egy protekcionista ország hajlandósága, hogy csatlakozik egy regionális integrációhoz, mutathatja az elmozdulást egy liberálisabb, befektetô barát kereskedelempolitika irányába.

A gyarmati korszakot követően függetlenné vált afrikai országok a regionális integrációk alakítását, a fejlesztéspolitikájuk szerves részének tekintették. Ebből következően ma Afrikában számos integráció működik, és minden afrikai ország tagja legalább egy integrációnak. Afrika jelenlegi geopolitikai képét a korábbi gyarmattartó európai hatalmaknak rajzolták ki, melynek eredménye, hogy sok területileg és gazdasági teljesítményben is kicsi, piaccal alig rendelkező és tengerparttól elzárt ország jött létre, így a termelésben és a termelési tényezők felhasználásában a méretgazdaságossági előnyök nem érvényesültek. Ezért már a korai regionalizáció korában elődleges cél a méretgazdaságosság megteremtése és a széttagoltság

22 WTO, 2011. 92-122. о.

23 Ossa, 2010. 1-23. o. 
megszűntetése volt. A jövőbeli gazdasági és politikai egységre úgy tekintettek, ami majd megadja a teret az iparosításra és a gazdasági fejlődésre. ${ }^{24}$ Ezzel ellentétben az 1960 és 1970-es években az afrikai országok közötti csoportosulások tagjai importhelyettesítő politikát folytattak és az integrációt arra használták, hogy növeljék a termelési kapacitásokat, amit a nagyobb piac biztosított is. Persze ezzel csak negatív hatást sikerült elérni, hiszen a tagok a sokkal hatékonyabb harmadik országoktól származó importjukat csökkentették le, sőt a bezárkózás politikája elválasztotta egymástól a hazai és külpiacokat, ezzel megszüntetve a hazai piacok versenyképességét, ami még fejlődni sem tudott a technológia transzfer hiánya miatt. Ez utóbbi komoly hatást gyakorolt a tranzakciós költségek növekedésére, mint a magas szállítási költségek, amit köszönhetnek a szegényes infrastruktúrának és banki szolgáltatásoknak is. ${ }^{25}$

A Kelet-afrikai Közösség megalapításáról szóló szerződést 1999. november 30-án írta alá a 3 alapító állam - Kenya, Tanzánia és Uganda - és 2000. július 7-én lépett életbe. A Kelet-afrikai Közösséget először 1967-ben alapították, de akkor csak 10 évig múködött. ${ }^{26} \mathrm{~A}$ hanyatlás okaként az eltérô politikai ideológiákat, az igazságtalan elosztási politikát, a közös gazdasági stratégia hiányát és az 1970-es években a térség országai között kialakult fegyveres konfliktusokat lehet megjelölni. ${ }^{27}$ Két további tagország - Ruanda és Burundi - 2007. július 1-jétôl teljes jogú tagjai a csoportosulásnak, amely székhelye Arushában, Tanzániában található. 2016 augusztusától a Keletafrikai Közösség tagja lett Afrika legfiatalabb állama Dél-Szudán is. ${ }^{28} \mathrm{Az}$ integráció céljai között kiemelt figyelmet szentel a belső kereskedelem ösztönzésének és a külső tagokkal szembeni fellépésnek, melynek következtében 2005-ben az integráció elérte a vámunió szintjét, majd 2010 óta már közös piacként működik. A következő lépcsőt jelentő monetáris unió létrehozásához az EAC már 2010-ben kérte az Európai Központi Bank iránymutatását, a létrehozandó intézményrendszerrel (Kelet-afrikai Központ Bank), és a konvergencia kritériumokkal kapcsolatban. ${ }^{29}$

A regionális integrációk közül a Kelet-afrikai Közösség egy közepesen integrált csoportosulás, afrikai viszonylatban jó az együttmúködés, azonban

\footnotetext{
${ }^{24}$ WTO, 2011. 92-122. o.

25 SHAMS, 2003. 39. o.

${ }^{26}$ EAC, 2020.

27 TARRÓSY, 2007. 44-55. o.

${ }^{28}$ EAC, 2020.

${ }^{29}$ Debrun ET AL., 2010.
} 
tagországonként nagyok az eltérések. A tagországok közül Kenya a legintegráltabb, majd Uganda következik, míg a legrosszabbul Dél-Szudán és Burundi teljesít. Az emberek szabad mozgása terén mutatják a tagországok a legszorosabb együttműködést, amit a makrogazdasági integráció követ. A gazdasági integrációban Ruanda a legjobban teljesítő, ami a könnyen átváltható pénznemének köszönhető. A tagországok leggyengébben a termelési dimenzióban teljesítenek, Burundi és Dél-Szudán integráltsága nagyon gyenge ezen a területen (1. sz. ábra). ${ }^{30}$

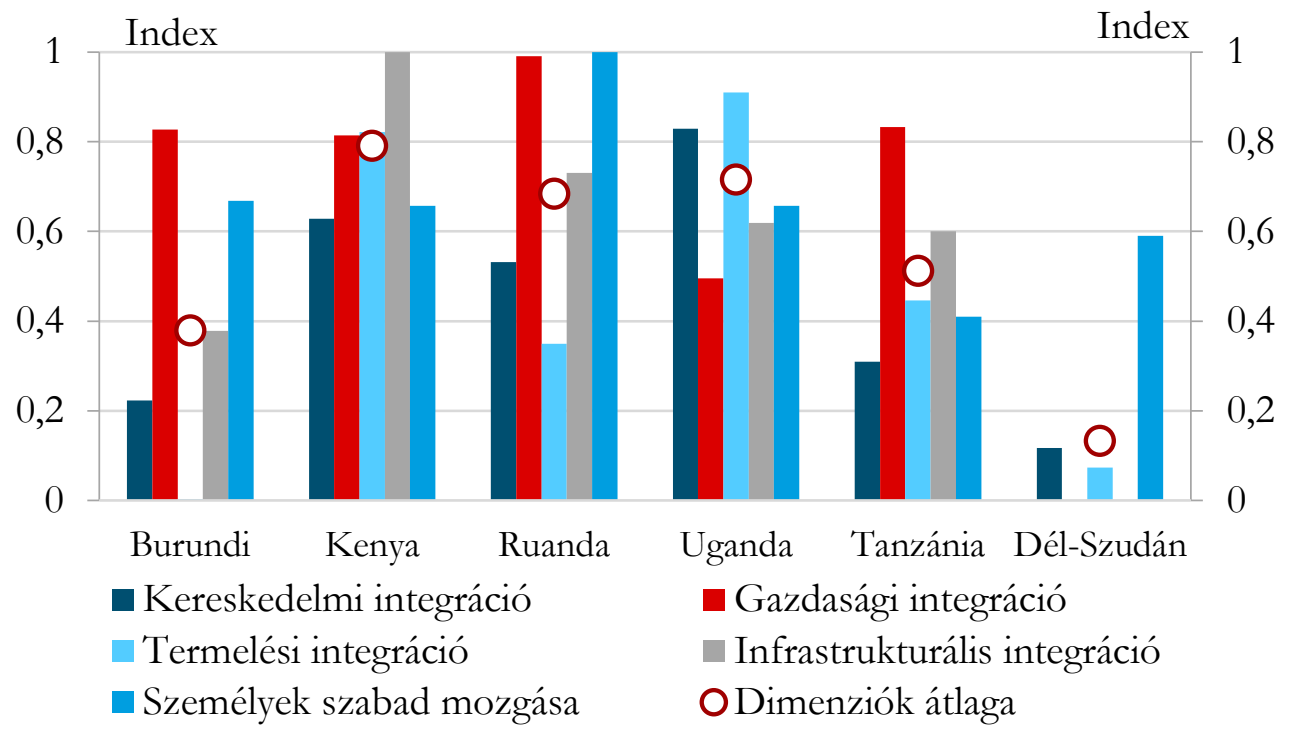

1. sz. ábra: A Kelet-afrikai Közösség tagországainak integráltsági indexe ${ }^{31}$, 2019. Megjegyzés: Az integráltsági index 0 és 1 között vehet fel értékeket, ahol az 1 jelenti a teljes integráltságot, az egyes dimenzióknál figyelembe vett mutatók esetén.

Ha Palánkai (2011) integrációérettséggel kapcsolatos módszertanának keretében vizsgáljuk a Kelet-afrikai Közösséget, akkor a monetáris integrációhoz kapcsolódó konvergencia kritériumok az alapot megadhatják a tagsági konvergenciához, de nem elegendőek a hatékony együttműködéshez. Egy ország akkor integrációérett, ha az integrációból származó haszna meghaladja a költségeit. Az integrációérettséget négy -

\footnotetext{
30 UNECA, 2019.

31 UNECA, 2019.
} 
gazdasági, politikai, társadalmi és intézményi - dimenzió eredőjeként vizsgálhatjuk. ${ }^{32}$ Sőt, Dél-Szudán tagsága további kérdéseket is felvet, amit integráltságának alacsony szintje is mutat. A kereskedelmi együttmúködések sikerességének az integrációérettség kevésbé szükséges feltétele, amit a tagországok kereskedelmi dimenzióban vett magas integráltsága is jelezhet, ezzel alátámasztva a kereskedelem vizsgálatának létjogosultságát. ${ }^{33}$

Ezt a Közösség belső kereskedelmének alakulása is alátámasztja, hiszen belső kereskedelmük dinamikusan növekszik. A növekedés dinamikája 2005-től a vámunió bevezetésével, majd 2010-től a közös piac megalakításával tovább erősödött (2. sz. ábra). Azonban itt is vannak tagországi különbségek, a kereskedelmi integráció terén Uganda és Kenya a legintegráltabb, míg Burundi belső kereskedelme egy viszonylag alacsonyabb szinten stabilizálódott az elmúlt időszakban.

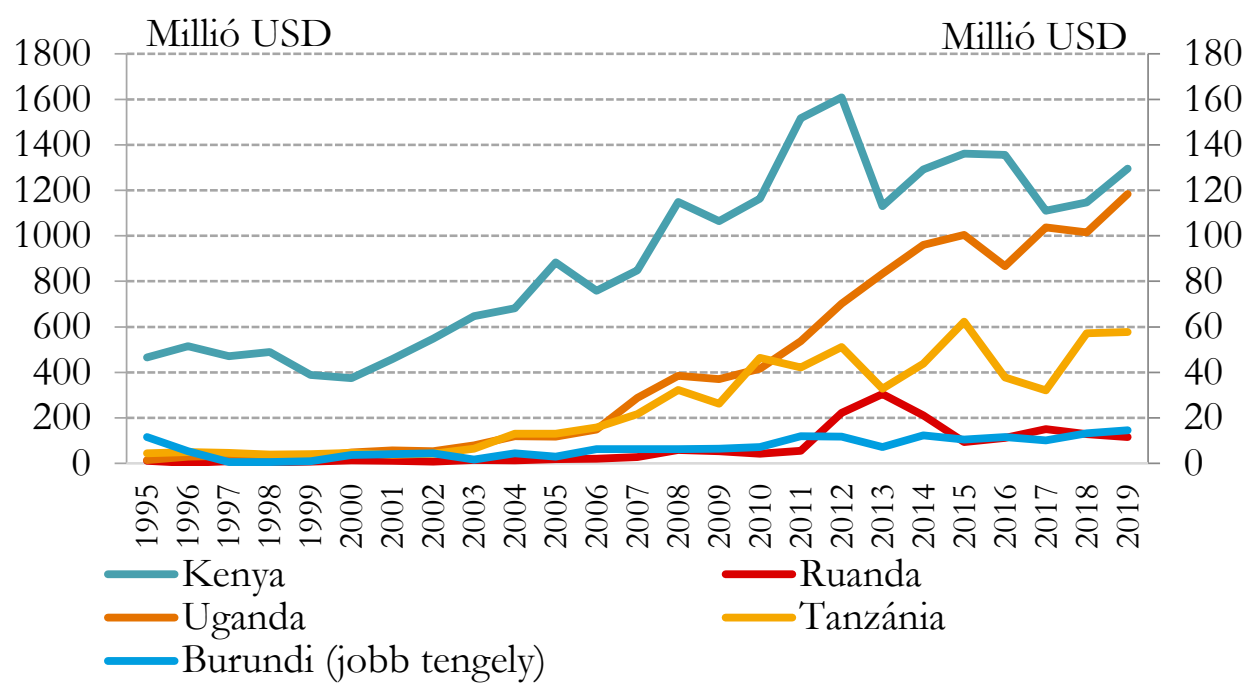

2. sz. ábra: A Kelet-afrikai Közösség belső kereskedelmének alakulása ${ }^{34}$ Megjegyzés: Dél-Szudán esetében nem áll rendelkezésre adat.

A Közösség kifelé irányuló kereskedelemének összetétele rámutat, hogy az exporton belül a mezőgazdaságához kapcsolódó termékek aránya

\footnotetext{
32 ENDRŐDI-KOVÁCS, 2013. 1-10. o.

33 PALÁNKAI, 2011. 357-358. o.

${ }^{34}$ UNCTADSTAT, 2020.
} 
50 százalék körül alakult az elmúlt években, vagyis elsődlegesen még mindig a primer szektor dominálja a kelet-afrikai gazdaságok termelési szerkezetét (3. sz. ábra).

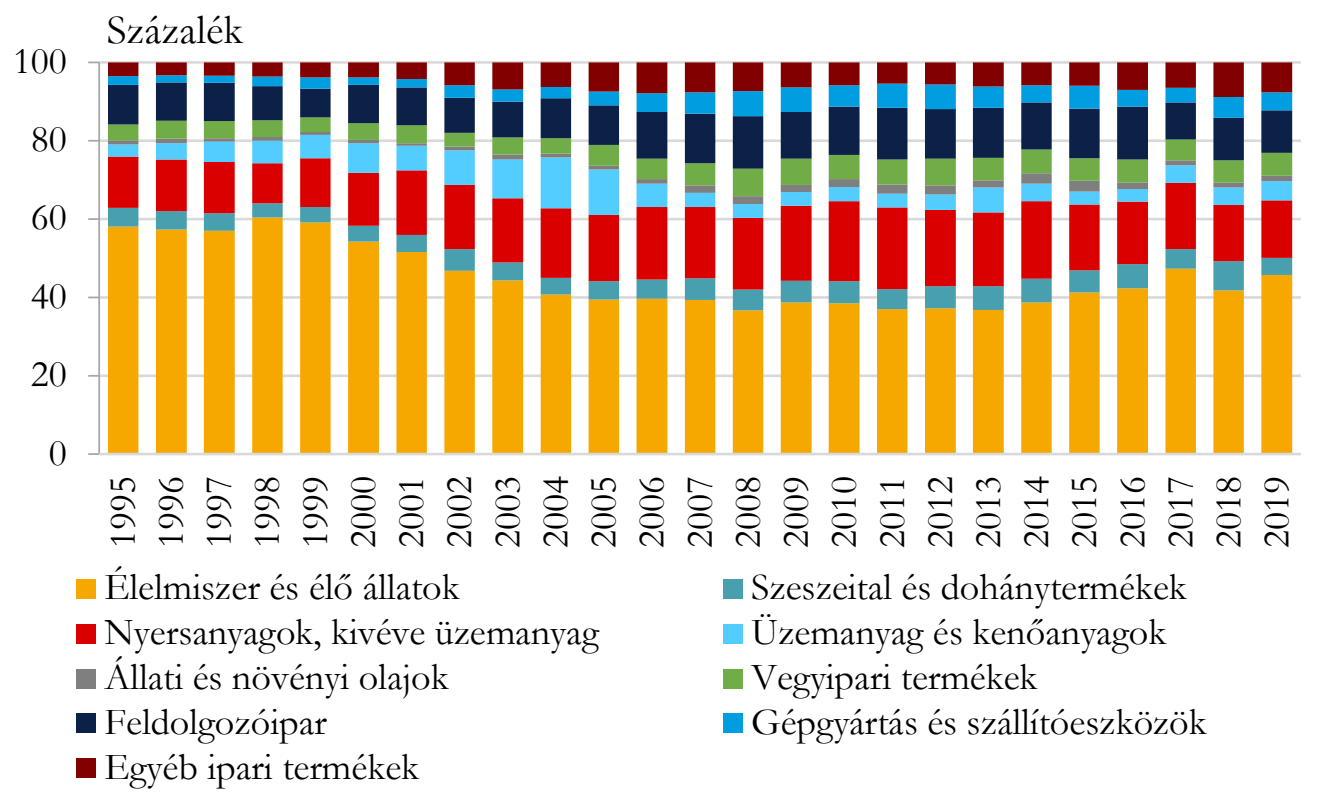

3. sz. ábra: A Kelet-afrikai Közösség kifelé irányuló exportösszetételének alakulása termékcsoportonként ${ }^{35}$

Azonban a belső kereskedelem terén az élelmiszerek az élő állatok a teljes belső export 30 százaléka körül alakulnak, míg az üzemanyagokat nem tartalmazó nyersanyagok, a szeszesital és dohánytermékek, illetve az állati és növényi olajok is tartósan 5-5 százalékos részarányt tesznek ki (4. sz. ábra). A kőolajszektorhoz kapcsolódó üzemanyagok és kenőanyagok kereskedelmi aránya alacsony, míg az ipari termelés részaránya fokozatosan növekszik. Az ipari termékek exportján belül a gépgyártás és szállítóeszközök mutatják a legnagyobb élénkülést, ami annak is köszönhető, hogy ez a szektor a külföldi működtőke befektetők kiemelt célterülete. Ebből következőleg nemcsak a kifelé irányuló exportszerkezetet javítja, hanem a belső áruszerkezetet is diverzifikálhatja. Sőt, technológia hatékonyságjavulást

35 UNCTADSTAT, 2020. 
vetíthet előre, ami a versenyképességet is növelheti, és tovább ösztönözheti a belső kereskedelmet, akár a Közösségen belül, akár régiós szinten. ${ }^{36}$

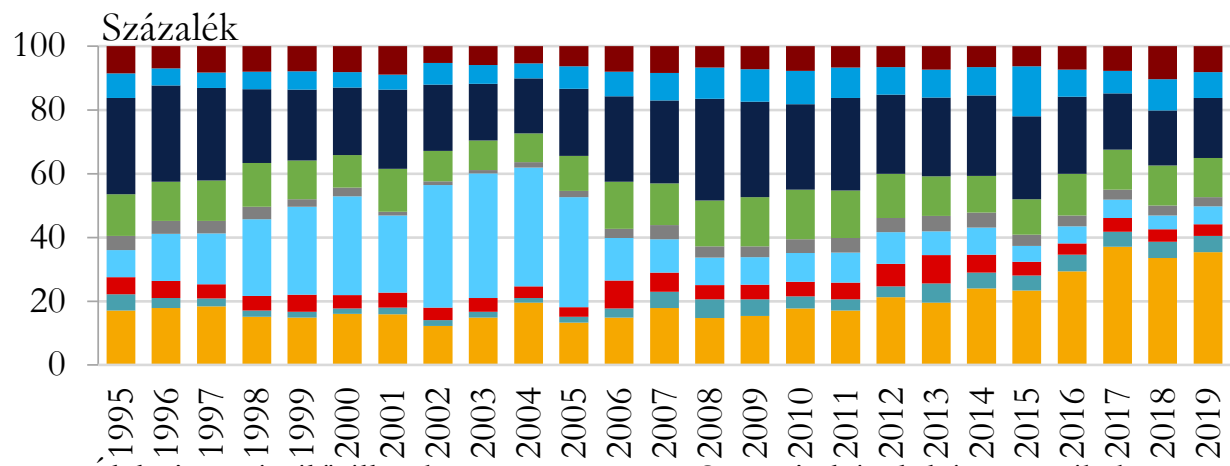

Élelmiszer és éló állatok

- Nyersanyagok, kivéve üzemanyag

- Állati és növényi olajok

- Feldolgozóipar
- Szeszeital és dohánytermékek

- Üzemanyag és kenőanyagok

- Vegyipari termékek

- Gépgyártás és szállitóeszközök

4. sz. ábra: A Kelet-afrikai Közösség belső exportösszetételének alakulása termékcsoportonként ${ }^{37}$

Az afrikai regionális integrációk már felismerték, hogy Afrikán belül is fontos az összefogás, így 2006-ban a Kelet-afrikai Közösség, a Kelet- és Dél-afrikai Közös Piaccal (angol elnevezés: Common Market for Eastern and Southern Africa, rövidítve: COMESA) és a Dél-afrikai Fejlesztési Közösséggel (angol elnevezés: Southern African Development Community, rövidítve: SADC) háromoldalú megállapodást kötött, melynek legfontosabb céljai, hogy harmonizálják az integrációk működését és előmozdítsák a kereskedelmet, amit főként az infrastruktúra fejlesztésével - szállítási idő csökkentése, így alacsonyabb költségek - kívánnak elérni. ${ }^{38}$ A Kelet-afrikai Közösség is felismerte, hogy a belső erőforrások nem elegendőek a szükséges beruházásokat megvalósításához, így már több Afrikán kívüli szervezettel is partnerségi megállapodásokat kötöttek, mint a Világbank, az Európai Unió, ${ }^{39}$ az Európai Központi Bank, a Svéd Nemzetközi Fejlesztési Együttműködési Hivatal, vagy a Norvég Fejlesztési Hivatal. Sőt több ország

\footnotetext{
36 GEDA-SEID, 2015. 19-50. o.

${ }^{37}$ UNCTADSTAT, 2020.

38 OECD, 2011.

${ }^{39}$ KIS, 2018, 86. o.
} 
külön fejlesztési programot dolgozott ki az afrikai régió fejlesztésére, mint a Tokiói Nemzetközi Afrikai Fejlesztési Konferencia vagy a Kína - Afrika Együttmúködési Fórum. ${ }^{40}$

2019-ben az Afrikába irányuló közvetlen külföldi tőkebefektetések már 10 százalékkal mérséklődtek az előző évhez képest. A kontinens egyes gazdaságaiba (például Egyiptom, Uganda, Togo, Elefántcsontpart) áramló több közvetlen külföldi tőkebefektetés nem tudta ellensúlyozni a szélesebb körű csökkenést (Nigéria, Dél-Afrikai Köztársaság, Etiópia). A nyersanyagárak mérséklődésével párhuzamosan a bányászat területén érdemben csökkent a zöldmezős beruházások száma. Hasonló tendencia volt megfigyelhető az élelmiszeripar és a vegyipar területén is. A legnagyobb emelkedést a járműipar és az energetika mutatta fel (1. táblázat). A 2000-es évek elejéig az Európai Unió és az Egyesült Államok dominálta az afrikai befektetéseket, azonban 2019-ig egy csökkenő tendencia azonosítható. E csökkenést külső tényezők is magyarázzák, hiszen a jelenlegi amerikai adminisztráció - a kereskedelmi korlátozások miatt - komoly bizonytalansági tényező a térséget illetően, továbbá a Brexitet övező bizonytalanságok is erősen éreztetik hatásukat. A zöldmezős beruházásoknál az Európai Unió mellett a kínai befektetések tették ki a legnagyobb részarányt Afrikában.

\begin{tabular}{|c|c|c|c|c|c|}
\hline Régiók & 2018 & 2019 & Szektorok & 2018 & 2019 \\
\hline Fejlett országok & 38793 & 39993 & Bányászat & 16782 & 2829 \\
\hline Európai Unió & 25725 & 28993 & Élelmiszeripar & 4660 & 2448 \\
\hline $\begin{array}{l}\text { Egyesült } \\
\text { Államok }\end{array}$ & 10565 & 3226 & Kőolajfeldolgozás & 6483 & 7727 \\
\hline $\begin{array}{c}\text { Egyesült } \\
\text { Királyság } \\
\end{array}$ & 5569 & 3102 & Vegyipar & 11159 & 6189 \\
\hline Fejlödô országok & 35915 & 36286 & Jármúipar & 2563 & 4015 \\
\hline Afrika & 5485 & 10002 & Energetika & 5712 & 10228 \\
\hline Kína & 11907 & 11915 & Építőipar & 4779 & 9576 \\
\hline Szaúd-Arábia & 2311 & 4443 & $\begin{array}{c}\text { Közlekedés, } \\
\text { raktározás }\end{array}$ & 5203 & 5402 \\
\hline $\begin{array}{l}\text { Egyesült Arab } \\
\text { Emírségek }\end{array}$ & 4118 & 5631 & $\begin{array}{l}\text { Információ, } \\
\text { kommunikáció }\end{array}$ & 3923 & 4639 \\
\hline
\end{tabular}

1. sz. táblázat: A bejelentett zöldmezős FDI beruházások száma Afrikában, földrajzi és szektoronkénti bontásban (millió USD) ${ }^{41}$

40 EAC, 2020, TARrósy, 2011, TARrósy, 2016. 237. o.

41 WORLD INVESTMENT REPORT, 2020. 29. o. 
A külföldi tőkebefektetések régiós átlagban fokozatos emelkedést mutatnak a Kelet-afrikai Közösségben. GDP arányosan 2013 óta Ugandában a legmagasabb az FDI állománya, majd Tanzánia és Ruanda következik (5. sz. ábra). Azonban a közvetlen külföldi tőkebefektetések Kelet-Afrikába Etiópiával együtt 9 százalékkal, 7,8 milliárd dollárra csökkentek 2019-ben. Kína volt a legnagyobb befektető 2019-ben, az újonnan jóváhagyott FDI-projektek 60 százalékát tette ki, a legtöbb projekt a feldolgozóiparra és a szolgáltatószektorra fókuszált. Az Ugandába érkező beáramlás érdemben, csaknem 20 százalékkal, 1,3 milliárd dollárra nőtt a főbb olajmezők, egy nemzetközi olajvezeték fejlesztése, valamint építőipari, feldolgozóipari és mezőgazdasági projektek miatt. A kenyai tőkebeáramlás 18 százalékkal, 1,3 milliárd dollárra csökkent, annak ellenére, hogy számos új projekt zajlott az informatika és az egészségügy területén. ${ }^{42}$

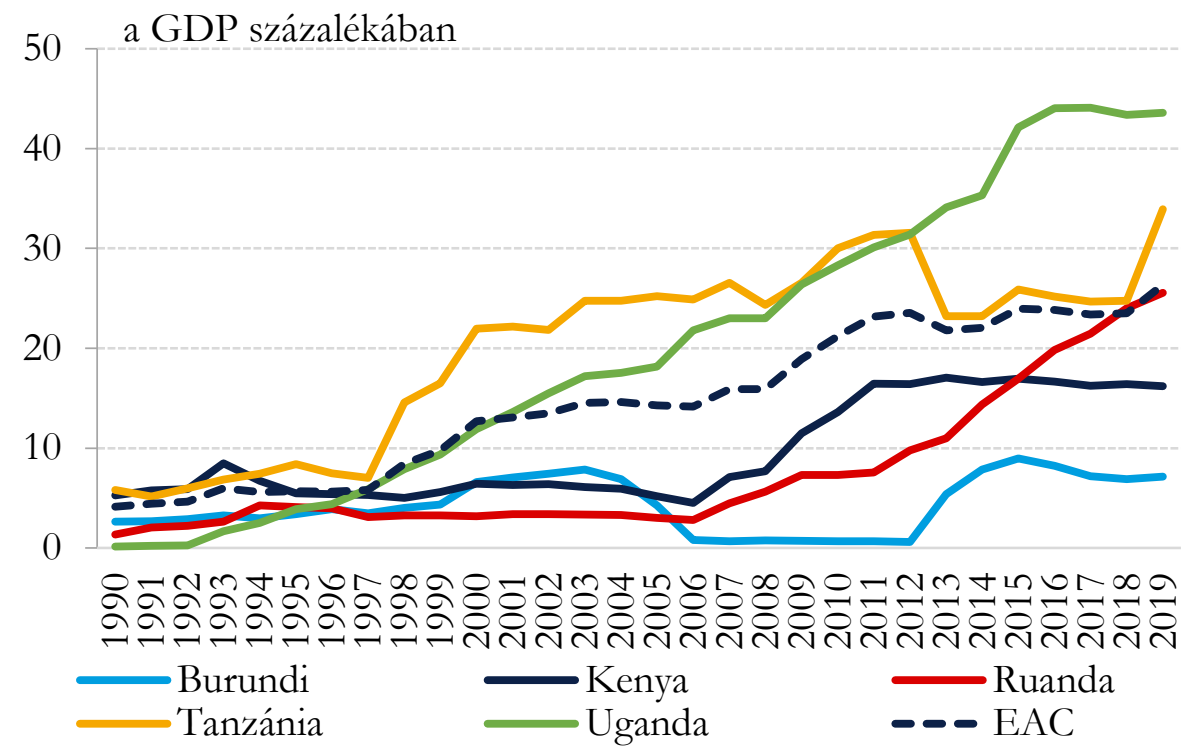

5. sz. ábra: A Kelet-afrikai Közösségbe áramló külföldi tőkebefektetések állománya ${ }^{43}$ Megjegyzés: Dél-Szudán esetében nem áll rendelkezésre adat.

\footnotetext{
42 WORLD INVESTMENT REPORT, 2020. 32. o.

43 UNCTADSTAT, 2020.
} 
Az Afrikába irányuló közvetlen tőkebefektetések egyre inkább technológiai és telekommunikációs iparágakba irányuló befektetéseket jelentenek, ami magyarázhatja és ösztönözheti a Kelet-afrikai Közösség belső kereskedelmében a magasabb hozzáadott értékű termékek egyre növekvő részarányát is. Persze a befektetések kiemelt célterületei között található az infrastruktúra és logisztika fejlesztése, az üzleti és pénzügyi szolgáltatások javítása, és a kiskereskedelemi szektor is, amit a háztartások egyre magasabb rendelkezésre álló jövedelme is segít. Ezzel összhangban a határon átnyúló infrastruktúra fejlesztése és az innováció maradtak a gazdasági növekedés fontos mozgatórugói, amelyhez az afrikai regionális integrációk, köztük a Kelet-afrikai Közösség mélyebb együttműködése további segítséget adhatna.

\section{A COVID-19 LEHETSÉGES HATÁSAI}

Az Afrikába irányuló befektetések alakulását nagyban befolyásolják a nemzetközi termelésben végmenő tendenciák. Két évtized gyors növekedését követően egy évtized stagnálás jellemezte a világkereskedelmet (2. sz. táblázat). Azt 1990-es éveket követően az országok fokozatos nyitásukkal (kereskedelem-liberalizáció) egyre jobban bekapcsolódtak a világgazdaság vérkeringésébe, az exportra alapozott növekedési politikák domináltak, amit a gyártási technológiák folyamatos fejlesztés is támogatott. 2010 után a protekcionista tendenciák visszatérésével, az FDI megtérülésének fokozatos csökkenésével és a technológia által lehetővé tett eszközök gyors terjedésével a nemzetközi kereskedelem lassulást mutatott.

A 2030-ig terjedő évtized indulásának nyugalmát szakított a félbe a COVID-19 megjelenése, ami a jelenlegi nemzetközi termelési rendszer megváltozásához vezethet. ${ }^{44}$ A regionális gazdasági együttmúködés, az iparpolitika és a beruházások ösztönzése nélkülözhetetlenné válik a regionális értékláncok kiépítéséhez, ami a Kelet-afrikai Közösség együttműködését is meghatározhatja a jövőben. Az új ipari forradalom vívmányai, a digitalizációhoz és a fenntarthatósághoz tartozó új megatrendek meghatározzák a 2020 utáni időszakot, az adat, mint erőforrás egyre nagyobb szerephez jut. ${ }^{45}$ A Big Data adatelemzésnek már konkrét keletafrikai eredményei is megemlíthetőek. A 2015-ös ugandai tífuszjárvány alatt

\footnotetext{
44 WORLD INVESTMENT REPORT, 2020. 12. o.

45 ERDÉLYI - KIS, 2019, 80. o.
} 
a kórházaktól gyújtött adatokat interaktív adatvizualizációs módszerrel elemezték, ami segített beazonosítani a fertőzött területeket és a betegség terjedését. Egy Ruandában végzett vizsgálat során erős együttmozgást találtak a mobiltelefon használat és bizonyos élelemiszerek (vitaminban gazdag zöldségek, húsfélék, gabonafélék) fogyasztása között, amivel a térség szegénységi mutatói jól közelíthetők. ${ }^{46}$

\begin{tabular}{ccc}
\hline $\begin{array}{c}\text { 1990-2010 } \\
\text { A növekedés tényezői }\end{array}$ & $\begin{array}{c}\text { 2010 után } \\
\text { A lassulás tényezői }\end{array}$ & $\begin{array}{c}\text { Új megatrendek, } \\
\text { Covid-19 lehetséges } \\
\text { hatásai }\end{array}$ \\
\hline $\begin{array}{c}\text { Exportvezérelt } \\
\text { növekedési politikák }\end{array}$ & $\begin{array}{c}\text { Protekcionizmus, } \\
\text { politikai } \\
\text { bizonytalanság }\end{array}$ & $\begin{array}{c}\text { Regionálizáció, } \\
\text { kereskedelmi } \\
\text { egyezmények }\end{array}$ \\
\hline $\begin{array}{c}\text { Kereskedelem- } \\
\text { liberalizáció, Csökkenő } \\
\text { kereskedelmi költségek }\end{array}$ & $\begin{array}{c}\text { FDI befektetések } \\
\text { hozamának } \\
\text { csökkenése }\end{array}$ & $\begin{array}{c}\text { Új megatrendek (AI, } \\
\text { automatizáció, } \\
\text { digitalizáció) }\end{array}$ \\
\hline Technolóigai újítások & Digitális technológiák & Fenntarthatóság \\
\hline
\end{tabular}

2. sz. táblázat: A nemzetközi termelési láncokat alakító tényezők ${ }^{47}$

A befektetési politika változása a pandémiára adott válaszok jelentős eleme. Számos többoldalú csoportosulás, köztük a G20-ak is nyilatkozat adtak ki a nemzetközi befektetések támogatásáról. Több mint 70 ország hozott intézkedéseket vagy a közvetlen külföldi befektetésekre gyakorolt negatív hatások enyhítésére, vagy a hazai ipar megóvására. A támogatási intézkedések magukban foglalják az online befektetések megkönnyítését, a befektetést ösztönző ügynökségek járványhoz kapcsolódó szolgáltatásait és az egészségügyi beruházások támogatását. Több ország szigorította a külföldi befektetések feltételeit az egészségügy és más stratégiai iparágak védelme érdekében. Több ország megtiltotta az orvosi eszközök kivitelét és az orvostechnikai eszközök behozatali vámját csökkentették. Emellett a válság lelassította a nemzetközi beruházási megállapodásokról szóló tárgyalások ütemét is. ${ }^{48}$

${ }^{46}$ HAJNAL - KIS, 2019. 311-312. o.

47 WORLD INVESTMENT REPORT, 2020. 126. o.

48 WORLD INVESTMENT REPORT, 2020. 11. o. 
A koronavírus-járvány hivatalosan 2020. február 14-én érte el az afrikai kontinenst: az első fertőzöttet akkor regisztrálták Egyiptomban. Afrikában más régiókhoz képest a napi fertőzések száma egyelőre kedvezőbb képet mutat, országonként némi eltéréssel. Ennek okai a fiatalabb korösszetétel, az alacsonyabb népsűrűség, valamint a korai lezárások. Azonban fontos megjegyezni, hogy a jelenleg kedvezőbb számokhoz valószínűsíthetôen az alacsonyabb tesztelési kapacitás is hozzájárul, így a fertőzési adatokat fenntartással kell kezelnünk. ${ }^{49}$

A tanulmány lezárásakor, 2020. október 10-én rendelkezésre álló adatok alapján a Kelet-afrikai Közösség országaiban összesen 59.021 főnél mutatták ki a koronavírus fertőzést és 958 ember veszítette életét a vírussal megfertőzöttek közül. ${ }^{50}$ Kenya igazolt napi esetszámai a nyár folyamán, Ruandában augusztus-szeptemberben, még Dél-Szudánban május-júniusban tetőztek. Burundiban alig volt igazolt fertőzés. A második hullám már Afrikában is kezd megjelenni, amit a kenyai esetszámok ismételt emelkedése is alátámaszt (6. sz. ábra).

\footnotetext{
49 TARRÓSY, 2020, 4. o.
}

50 AFRICACDC, 2020. 


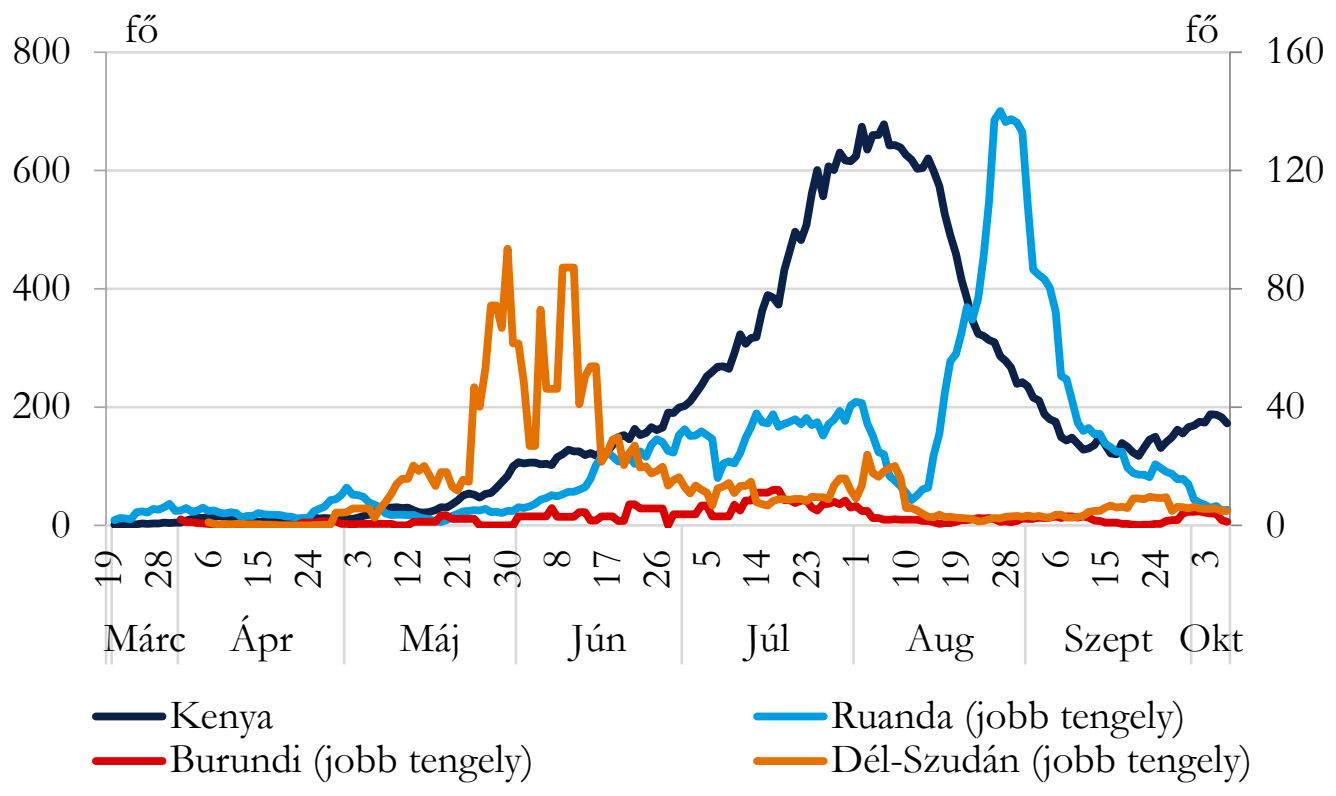

6. sz. ábra: Az igazolt COVID-19 fertőzöttek napi számának alakulása (7 napos mozgóátlag), ${ }^{51}$ Megjegyzés: Tanzánia és Uganda esetében nem áll rendelkezésre idősoros adat.

A gazdasági következmények Afrikában súlyosak lesznek, ami több csatornán keresztül fejti ki hatását. ${ }^{52}$

1. Egészségügyi okok miatt csökkenő kereslet: A növekvő humanitárius költségek mellett az ipari termelés is akadozhat, a munkahelyek bezárása, az ellátási láncok megszakadása és a munkától egészségügyi okokból távolmaradók miatt. Példaként említve Ruanda ipari termelése 24,4 százalékkal, míg a Dél-afrikai Köztársaságé 31,9 százalékkal csökkent éves bázison 2020 második negyedévében. ${ }^{53}$ Ezzel párhuzamosan a rendelkezésre álló jövedelem, a fertőzéstôl való félelem és a fokozott bizonytalanság mind a keresletet csökkenését eredményezi.

2. Globális növekedési visszaesés: A kereskedelem szempontjából a kulcsfontosságú kereskedelmi partnerek érdemi növekedési

51 JOHN HOPKINS UNIVERSITY, 2020.

${ }^{52}$ IMF, 2020. 3-5. o.

${ }^{53}$ Trading ECONOMICS, 2020. 
visszaesése csökkenti a külső keresletet. Az ellátási lánc megszakadása csökkenti az importált áruk elérhetőségét, ami a magasabb árak miatt inflációs nyomást gyakorolhat a gazdaságokra. A globális pénzügyi feltételek szigorítása csökkenti a régióba irányuló befektetéseket, ami megnehezíti az egészségügyi válság kezelését, a növekedés támogatását és árfolyamra is nyomást gyakorol. A vírus olyan iparágakat támadott meg, ami sok afrikai országnak a növekedés támaszát jelentette. A turizmusra erősen támaszkodó országok (pl. Zöld-foki szigetek, Comore-szigetek, Gambia, Mauritius, São Tomé és Príncipe, Seychelle-szigetek) gazdasági teljesítménye érdemben csökkent 2020 második negyedévében. Mauritius és a Zöld-foki szigetek GDP-je közel harmadát elvesztette, míg a Seychelle-szigetek visszaesése 17,2 százalék volt éves összevetésben. ${ }^{54}$ A nemzetközi turisztikai kereslet várhatóan csak 2023 után tér vissza a 2019-es szintre, így ezek az országok egy elhúzódó kilábalással nézhetnek szembe. ${ }^{55}$

3. Csökkenő nyersanyagárak: A nyersanyagárak meredek csökkenése további sokkot jelent az afrikai régió erőforrás-exportra támaszkodó országai (Angola, Kamerun, Csád, Gabon, Nigéria, EgyenlítőiGuinea) számára, tovább súlyosbítva a járvány hatását. A Brent típusú kőolaj hordónkénti jegyzésára több mint 50 százalékkal, 31 dollárig esett a második negyedévben, ami októberig csak mérsékelt korrekciót mutatott. ${ }^{56}$ A súlyos cserearány romlás nehezíti a növekedést, és növeli ezeknek az országoknak a fiskális és külső sérülékenységét.

A Kelet-afrikai Közösség sérülékenységét megvizsgálva elsősorban a turizmusnak való kitettség és az egészségügyi rendszer hiányosságai jelentik a legnagyobb kockázatot. Emellett országspecifikus tényezők is megjelennek. Kenya esetében a globális pénzügyi piacokkal való szorosabb kapcsolat, illetve az Európával és Kínával folytatott kereskedelem magas sérülékenységét eredményez, ez utóbbi Dél-Szudán esetében is kockázati tényezőként jelentkezik. Emellett az államadósság finanszírozása Kenya mellett Burundi kitettségét is növeli (3. sz. táblázat). A jelenleg rendelkezésre álló a Kelet-afrikai Közösség országaira vonatkozó növekedési adatok még főként a lezárások hatásait tükrözik. 2020 második negyedévében a bruttó hazai termék volumene Kenyában 5,7 százalékkal, Ugandában 6 százalékkal

\footnotetext{
54 TRADING ECONOMICS, 2020.

${ }^{55}$ IMF, 2020. 6. o.

56 BloOmberg, 2020.
} 
míg Ruandában 12,4 százalékkal esett az előző év azonos időszakához képest. ${ }^{57} \mathrm{~A}$ járvány lefutása és lehetséges elhúzódása előretekintve is kiemelt bizonytalansági tényező.

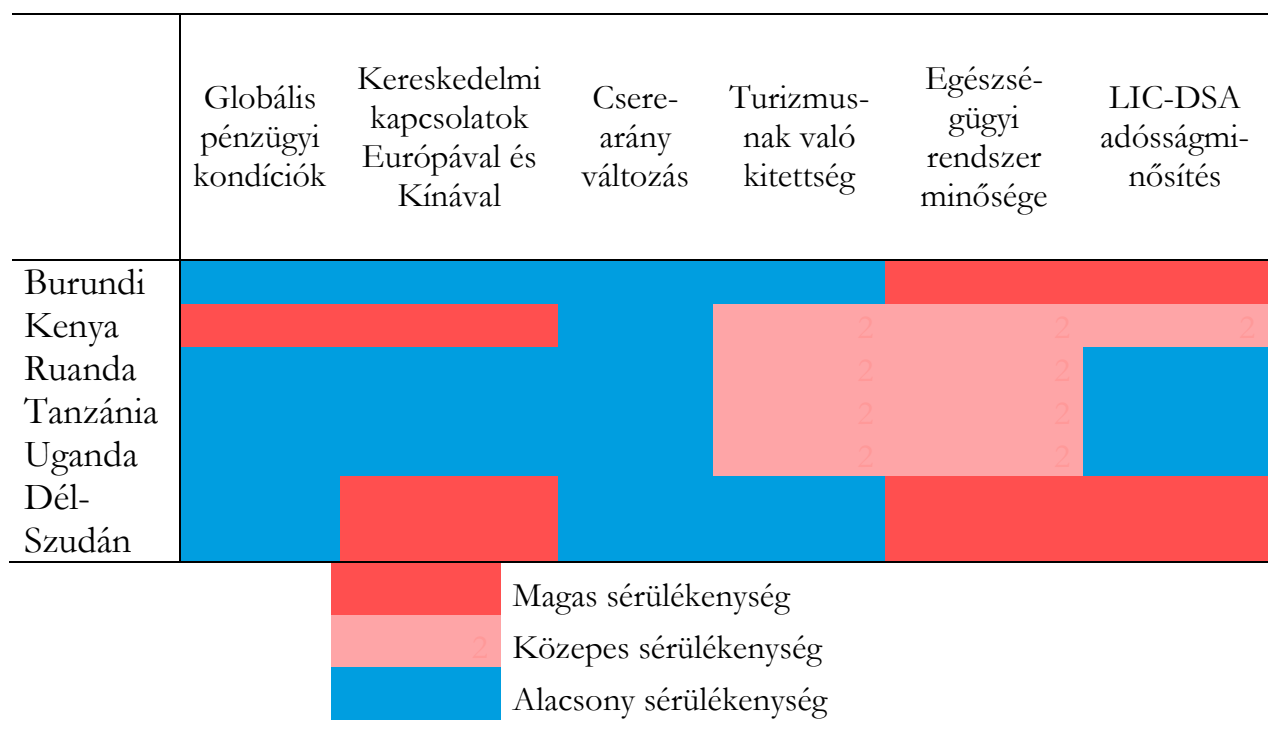

3. sz. táblázat: A Kelet-afrikai Közösség tagországainak sérülékenysége a COVID-19 hatásaival szemben ${ }^{58}$

Megjegyzés: LIC-DSA: Debt Sustainability Framework for Low-Income Countries.

A széles körben elterjedt gazdasági bizonytalanság és a kijárási korlátozások miatt sok bejelentett és tervezett beruházási projekt elhalasztásra került. 2020 áprilisától az Afrikára irányuló határokon átnyúló egyesülések és felvásárlások száma 72 százalékkal csökkent a 2019. havi átlaghoz képest. Bár a járvány minden iparágat érint, számos szolgáltató iparágat aránytalanul sújt, beleértve a légiközlekedést, a vendéglátást, az idegenforgalmat és a szabadidős tevékenységeket. Ezek az iparágak együttesen adták 2019-ben a bejelentett zöldmezős projektek mintegy 10 százalékát Afrikában. A feldolgozóipar - amely a bejelentett zöldmezős

57 TRADING ECONOMICS, 2020.

$58 \mathrm{IMF}, 2020.4$. o. 
projektek további 7 százalékát tette ki 2019-ben - szintén jelentősen érintett, ami aggodalomra ad okot a gazdasági diverzifikáció és az iparosítás előmozdítására irányuló erőfeszítések terén. A koronavírus hatása már számokban is mérhető, a zöldmezős beruházások száma 23 százalékkal, értékük 62 százalékkal esett 2020 első negyedévében az előző év azonos időszakához képest, amihez az alacsony olajárakkal párhuzamosan elhalasztott beruházások elmaradása is hozzájárult. ${ }^{59}$

Kezdeményezés

\begin{tabular}{|c|c|c|}
\hline $\begin{array}{l}\text { Egyesült } \\
\text { Államok }\end{array}$ & $\begin{array}{l}\text { Prosper Africa } \\
\text { Initiative (2019) }\end{array}$ & $\begin{array}{l}5 \text { milliárd \$ az etióp ipar } \\
\text { fejlesztésére 2020-ig }\end{array}$ \\
\hline Kína & $\begin{array}{c}\text { Forum on China- } \\
\text { Africa Cooperation } \\
\text { (2010, utolsó ülés 2018- } \\
\text { ban) }\end{array}$ & $\begin{array}{l}\text { Partmenti vasúthálózat } \\
\text { Nigériában (12 milliárd \$), Addis } \\
\text { Ababa - Djibouti vasúthálózat } \\
(4,5 \text { milliárd } \$) \text {, kikötő } \\
\text { Tanzániában }(11 \text { milliárd } \$)\end{array}$ \\
\hline $\begin{array}{l}\text { Egyesült } \\
\text { Királyság }\end{array}$ & $\begin{array}{l}\text { United Kingdom- } \\
\text { Africa Investment } \\
\text { Summit (2020 január) }\end{array}$ & $\begin{array}{l}\text { Olajkitermelés Kenyában } \\
\qquad(1,5 \text { milliárd \$) }\end{array}$ \\
\hline Oroszország & $\begin{array}{l}\text { Russia-Africa Summit } \\
\text { and } \\
\text { Economic Forum } \\
\text { (2019 október) }\end{array}$ & $\begin{array}{l}\text { Olajfinomító Marokkóban } \\
\qquad(2,2 \text { milliárd \$) }\end{array}$ \\
\hline Franciaország & $\begin{array}{c}\text { Choose Africa (2019 } \\
\text { december) }\end{array}$ & $\begin{array}{l}\text { Mezőgazdasági beruházások } \\
\text { Szubszaharai Afrikában }\end{array}$ \\
\hline
\end{tabular}

4. sz. táblázat: Beruházási kezdeményezések Afrikában ${ }^{60}$

Az afrikai közvetlen külföldi befektetések közvetlen negatív kilátásai ellenére néhány enyhítő tényező mérsékelheti a befektetések visszaesését és 2021-től elősegítheti a kilábalást. Egyrészrôl a nagyobb globális gazdaságok, elsősorban az Egyesült Államok és Kína, de az Egyesült Királyság, az Oroszország és Franciaország is fontosnak tatja a kontinenssel való

\footnotetext{
${ }^{59}$ WORLD INVESTMENT REPORT, 2020. 31. o.

60 WORLD INVESTMENT REPORT, 2020. 33. o.
} 
befektetési kapcsolatokat. Az ezen országok által támogatott beruházási kezdeményezések egy része az infrastruktúrára összpontosít, különösen a kínai kezdeményezések. Mások a természeti erőforrásokat és a gyártási kapacitások kiépítését célozzák. Az új francia kezdeményezés, a Choose Africa, például kifejezetten olyan kis és közepes méretű projektek számára készült, amelyek hozzájárulnak a helyi termelési kapacitásokhoz és a munkahelyteremtéshez (4. sz. táblázat). Emellett az Afrikai Kontinentális Szabadkereskedelmi Övezetről (angol elnevezés: African Continental Free Trade Area, rövidítve: AfCFTA) szóló megállapodás szintén támogatást nyújthat a kontinensen múködő közvetlen külföldi befektetéseknek. Különösen a kontinensen belüli beruházások kaphatnak pozitív ösztönzést, a beruházási protokoll 2020 decemberére tervezett véglegesítése után. ${ }^{61}$

\section{KONKLÚZIÓ}

A Kelet-afrikai Közösség megalakítása hosszú évtizedekre nyúlik vissza, de az ezredforduló utáni újraszervezése az integráció eredményességére is komoly hatást gyakorolt. Belső kereskedelmük dinamikusan emelkedett a 2005-ben bevezetett közös vámszabályok, de különösen a 2010-ben létrehozott közös piac megalakítása után. Kereskedelmüket még mindig a primer termékek dominálják, azonban a belső kereskedelem terén egyre nagyobb arányban találunk magasabb hozzáadott értékű termékeket (jármúipar, gépgyártás) és szolgáltatásokat. A belső kereskedelem élénkítése pedig a tagországok integráltságát javítja, ezáltal hozzájárulhat az erőforrások hatékonyabb elosztásához és a termelési folyamatok összehangolásához is, ami a beáramló tôke produktívabb felhasználást segítheti, ezzel elindítva egy fejlődési spirált. Ráadásul a politikai stabilitás növelése és a szabályozó környezet javítása tovább növelheti az FDI beáramlását, ezzel tovább segítve a régió gazdasági növekedését is. A pozitív változások elindultak, hiszen a Kelet-afrikai Közösségbe egyre több múködőtőke áramlik.

Azonban az Afrikába irányuló befektetések alakulását nagyban befolyásolják a nemzetközi termelésben végmenő tendenciák. Két évtized gyors növekedését követően egy évtized stagnálás jellemezte a világkereskedelmet. A 2030-ig terjedő évtized indulásának nyugalmát szakított a félbe a COVID-19 megjelenése, ami a jelenlegi nemzetközi

${ }^{61}$ WORLD INVESTMENT REPORT, 2020. 30-32. o. 
termelési rendszer megváltozásához vezet, ami alól az afrikai országok sem vonhatják ki magukat. A koronavírus megjelenése az afrikai országok gazdaságára számos csatornán keresztül hatással van. Egyrészről nagy terhet ró az egyébként is alacsonyabb hatékonysággal múködő egészségügyi rendszerre. Emellett a belső kereslet csökkenése párosulva a külső kereskedelmi partnerek keresletének visszaesésével érdemi negatív hatást gyakorol a gazdasági teljesítményre. Ezt tovább mélyíti, hogy a koronavírus a gazdaságok növekedésének támaszát támadta meg. A légiközlekedés, a vendéglátás és az idegenforgalom leállása a turizmusnak kitett országok esetében gyakorlatilag teljes bevételkiesést jelentett, míg az alacsony kereslettel összefüggésben a nyersanyagárak mélyrepülése az erőforrásokra támaszkodó országokban jelent nagyobb kihívást. A befektetési politika változása a koronavírusra adott válaszok jelentős eleme. A külföldi tőkebefektetések és a zöldmezős beruházások érdemi csökkenését a 2020 első negyedévi adatok már láthatóvá tették. Előretekintve a kilábalás hossza kérdéses, ami Afrikában nagyban függ a globális nagybefektető országok viselkedésétől, illetve az Afrikai Kontinentális Szabadkereskedelmi Övezet jövőbeli hatékonyságától is.

\section{FELHASZNÁLT IRODALOM}

Adams, SAmuel - Evans Osei Opoku, Eric (2015): Foreign direct investment, regulations and growth in sub-Saharan Africa. Economic Analysis and Policy, Vol. 47. (Letöltve: 2020. 08. 23.)

Adjasi, Charles K. D. - Abor, Joshua - Osei, Kofi A. - Nyavor-Foli, ERNESTINE E. (2012): FDI and Economic Activity in Africa: The role of local financial markets. Thunderbird International Business Review, Vol. 54, No. 2. https://doi.org/10.1002/tie.21474 (Letöltve: 2020. 09. 10.)

AfriCACDC (2020): Coronavirus Disease 2019 (COVID-19). Elérhető: https://africacdc.org/covid-19/ (Letöltve: 2020. 10. 10.)

Amighini, ALESSiA - SANFILIPPO, MARCO (2014): Impact of South-South FDI and Trade on the Export Upgrading of African Economies. World Development, Vol. 64, https://doi.org/10.1016/j.worlddev.2014.05.021 (Letöltve: 2020. 08. 23.)

AREZKI, RABAH - SY, AMADOU (2016): Financing Africa's infrastructure deficit: from development banking to long-term investing, Global Economy and Development, No. 2. (Letöltve: 2020. 08. 23.) 
Asideu, ElizABETH (2006): Foreign direct investment in Africa: the role of natural resources, market size, government policy, institutions and political instability. World Economy, Vol. 29. No. 1. https://doi.org/10.1111/j.1467-9701.2006.00758.x (Letöltve: 2020. 08. 23.)

BloOMBERG (2020): Oil price futures. Elérhető: https://www.bloomberg.com/europe (Letöltve: 2020. 10. 28.)

CHRIST, NANNETTE - FERRANTINO, MiCHAEL J. (2011): Land transport for export: the effects of cost, time, and uncertainty in Sub-Saharan Africa, World Development, Vol. 39. No. 10. (Letöltve: 2020. 09. 10.)

Debrun, Xavier - Masson, Paul - Pattilo, Catherine (2010): Should African Monetary Unions Be Expanded? An Empirical Investigation of the Scope for Monetary Integration in Sub-Saharan Africa. Working Paper, 10/157, International Monetary Fund. https://doi.org/10.5089/9781455201402.001 (Letöltve: 2020. 09. 10.)

EAC (2020): East African Community, About EAC. Elérhető: https://www.eac.int/ (Letöltve: 2020. 10. 10.)

EIB (2015): Recent Trends in Banking in sub-Saharan Africa, from Financing to Investment. European Investment Bank. Elérhető: https://www.eib.org/attachments/efs/economic report banking africa from financing to investment en.pdf (Letöltve: 2020. 06. 23.)

ENDRŐDI-KOVÁCS MÓNIKA (2013): Az integrációérettség elméletének továbbgondolása és kiterjesztése. Köz-gazdaság, Vol. 1. (Letöltve: 2020. 09. 10.)

ERDÉLYI LEVENTE - KIS KATALIN (2019): Hogyan tartsunk lépést a technológiával? In.: Virág Barnabás (szerk.): A jövő fenntartható közgazdaságtana. Magyar Nemzeti Bank, Budapest. 73-87. o.

FrANCOIS, JOSEPH - MANCHIN, MiRIAM (2013): Institutions, infrastructure and trade, World Development, Vol. 46. https://doi.org/10.1016/j.worlddev.2013.02.009 (Letöltve: 2020. 06. 23.)

Fuchs. Andreas - Dreher, Axel - Nunnenkamp, Peter. (2014): Determinants of donor generosity: A survey of the aid budget literature. World Development, Vol. 56. https://doi.org/10.1016/j.worlddev.2013.09.004(Letöltve: 2020. 09. 10.) Geda, Alemayehu - SeID, Hussein SeId (2015): The potencial for internal trade and regional integration in Africa. Journal of African Trade, Vol. 2. No. 1-2. https://doi.org/10.1016/i.joat.2015.04.001 (Letöltve: 2020. 09. 10.) 
Hajnal MihÁly - Kis KATAlin (2019): Az információ (adat) az új olaj In.: Virág Barnabás (szerk.): A jövő fenntartható közgazdaságtana. Magyar Nemzeti Bank, Budapest. 299-318. o.

IMF (2017): Making Trade an Engine of Growth for All: The Case for Trade and for Policies to Facilitate Adjustment. International Monetary Fund, The World Bank, World Trade Organization, Frankfurt, Germany. Elérhetô:

https://www.wto.org/english/news e/news17 e/wto imf report 0704 2017.pdf (Letöltve: 2020. 09. 10.)

IMF (2020): Regional Economic Outlook. Sub-Saharan Africa, COVID-19: An Unprecedented Threat to Development. Internation Monetary Fund. Elérhetô:

https://www.imf.org/en/Publications/REO/SSA/Issues/2020/04/01/ sreo0420 (Letöltve: 2020. 09.26.)

JAUMOTTE, Florence (2004): FOREIGN DireCT INVESTMENT AND REgiOnAL TRADE AgreEMENTS: THE market size effect revisited. Working Paper, 04/206, International Monetary Fund. https://doi.org/10.5089/9781451874631.001 (Letöltve: 2020. 09.10.)

JOHN HOPKINS UNIVERSITY (2020): New cases of COVID. Elérhető: https://www.jhu.edu/ (Letöltve: 2020. 10. 10.)

KIS KATALIN (2018): Az Európai Unió kereskedelempolitikája a kelet- és dél-afrikai régióban - A Kelet-afrikai Közösség (EAC) és a Dél-afrikai Fejlesztési Közösség (SADC) példáján. Európai Tükör, Vol. 21. No. 3. (Letöltve: 2020. 09. 10.)

Kodongo, OdOngo - OJAH, KALu (2016) Does infrastructure really explain economic growth in Sub-Saharan Africa? Review of Development Finance, Vol. 6. $\quad$ No. 2. https://doi.org/10.1016/i.rdf.2016.12.001 (Letöltve: 2020. 09. 10.)

Moussa, Mohamed - Caha, Havva - Karagöz, Murat (2016): Review of economic freedom impact on FDI: New evidence from fragile and conflict countries. Procedia Economics and Finance, Vol. 38. https://doi.org/10.1016/s2212-5671(16)30187-3 (Letöltve: 2020. 09. 10.)

OECD (2011): Aid for Trade case story. The COMESA-EAC- SADC Tripartite Trade and Transport Facilitation Programme. OECD, South Africa. Elérhető: https://www.oecd.org/aidfortrade/47407250.pdf (Letöltve: 2018. 10. 02.) 
Okafor, Godwin - Piesse, Jenifer - Webster, Allan (2015): The motives for inward FDI into Sub-Saharan African countries. Journal of Policy Modelling, Vol. $37 . \quad$ No. 5. https://doi.org/10.1016/j.jpolmod.2015.07.003 (Letöltve: 2020. 09. 10.) OsSA, RALPH (2010): A new trade theory of GATT/WTO negotiation. Working Paper, 16388, NBER Working Papers Cambridge MA. National Bureau os Economic Research, Cambridge. Elérhető: https://www.nber.org/papers/w16388.pdf (Letöltve: 2020. 09. 10.)

PALÁNKAI TiBOR (2011): Csatlakozási és tagsági kritériumok integrációérettség. In: Palánkai Tibor et al. (szerk.): A globális és regionális integráció gazdaságtana. Akadémiai Kiadó, Budapest.

SHAMS, RASUl (2003): Regional Integration in Developing Countries: Some Lessons Based in Case Studies. Discusson Paper, 251, Hamburg Institute of International Economics, Hamburg, Germany. https://doi.org/10.2139/ssrn.475781 (Letöltve: 2020. 09. 10.)

SZENT-IVÁNYI BALÁZS - VIGVÁRI GÁBOR (2012): Spillovers from foreign direct investment in Central and Eastern Europe. Society and Economy, Vol. 34. No. 1. https://doi.org/10.1556/socec.34.2012.1.5 (Letöltve: 2020. 09. 10.)

TAHIR MuHAMmad - KHAN, ImRAN - SHAH, AFZAL Moshadi (2015): Foreign Remittances, Foreign Direct Investment, Foreign Imports and Economic Growth in Pakistan: A Time Series Analysis. Arab Economics and Business Journal, Vol. 10. No. 2. https://doi.org/10.1016/j.aebj.2015.06.001 (Letöltve: 2020. 09. 10.)

TARRÓSY IsTVÁN (2007): Kenya-Uganda-Tanzánia Kelet-afrikai Föderáció álom vagy valóság? Afrika Tanulmányok, Vol. 1. No. 1. (Letöltve: 2020. 09. 10.)

TARrósy István (2011): Kelet-Afrika a fejlődés útján. Pécs, Publikon Kiadó.

TARRÓSY ISTVÁN (2013): Afrikai perspektívák egy új világrendben. In.: Grünhut Zoltán - Vörös Zoltán (szerk.): Az átalakuló világrend küszöbén, Publikon Kiadó, Pécs. 275-298. o.

TARRÓSY ISTVÁN (2016): Afro-ázsiai dinamikák: tanulmányok ázsiai államok afrikai szerepvállalásairól. Publikon Kiadó, Pécs.

TARRÓSY ISTVÁN (2020): Afrika a COVID-19 pandémia szorításában. KKI Elemzések, No. 47.

TRADING ECONOMICS (2020): Statistical data. Elérhető: https://tradingeconomics.com/ (Letöltve: 2020. 10. 28.) 
UNCTAD (2009): Economic Development in Africa Report 2009, Strengthening Regional Economic Integration for Africa's Development. United Nations Conference on Trade and Development, Geneva. Elérhető: https://unctad.org/en/docs/tdb56d4 en.pdf (Letöltve: 2019. 04.03.)

UNCTADSTAT (2020): UNCTADStat. Elérhető: https://unctadstat.unctad.org/EN/ (Letöltve: 2020. 09.26.)

UNECA (2020): Africa Regional Integration Index 2019. Elérhető: https://www.uneca.org/publications/africa-regional-integration-indexreport-2019 (Letöltve: 2020. 09.26.)

WORLD INVESTMENT REPORT (2020): UNCTAD - World Investment Report - 2020. Elérhető: https://unctad.org/system/files/officialdocument/wir2020 en.pdf (Letöltve: 2020. 09.26.)

WTO (2011): The WTO and preferential trade agreements: From coexistence to coherence. World Trade Report, 2011. World Trade Organization, Geneva. Elérhető: https://www.wto.org/english/res e/booksp e/anrep e/world trade re port11 e.pdf (Letöltve: 2018. 09. 10.) 